HOW LONDON AND ITS CONFLICTS CHANGED SHAPE:

\title{
$1758-1834$
}

Charles Tilly and R. A. Schweitzer University of Michigan

July 1982

Coples available through: Center for Research on Social Organization University of Michigan 330 Packard Street

Ann Arbor, Michigan 48109 


\section{How London and its conflicts changed shape: 1758-1834}

Charles Tilly

R. A. Schweitzer

Center for Research on Social Organization

University of Michigan

British Popular Politics in the Eighteenth and Nineteenth Centuries'

In his Colloquies on Society of 1824, Robert Southey had the ghost of Sir Thomas More speak his distress over what England-and especially the terrible metropolis of London-had become. "Think for a moment," fretted the ghost,

What London, nay, what the whole kingdom would be, were your Catilines to succeed in exciting as general an insurrection as that which was raised by one madman in your own childhood. Imagine the infatuated and infuriated wretches, whom not Spitalfields, St. Giles's, and Pimlico alone, but all the lanes and alleys and cellars of the metropolis would pour out-a frightful population, whose multitudes, when gathered together, might almost exceed belief! The streets of London would appear to teem with them, like the land of $E_{g y p t}$ with its plague of frogs: and the lava foods from a volcano would be less destructive than the hordes whom your great cities and manufacturing districts would. vomit forth! ${ }^{2}$

Francis Place (ordinarily no friend of the mob) offered a possible rejoinder to Southey fourteen years later:

There is, upon the whole, more honesty and more determination of purpose among the enlightened portion of the people than ever before existed in this or any other country. Of this the whole of the proceeding to obtain a reform of the house of commons is incontrovertible proof. In no other country, nor in this at any other time, could a change of such importance as the passing of the Reform Bills been [sic] affected, in the same quiet way by the same means. It was perhaps the greatest change ever accomplished in a civilized country by peaceable means.'

When Place wrote in 1838, the struggles of Chartism, as we know now, were soon to break the calm. Lauding the orderly action of the common people, furthermore, was an indirect way of justifying the line Place himself had taken during the Reform agitation and of taking credit for its success. Yet Place was surely right to claim that new forms of popular politics had emerged.

The nine decades between 1750 and 1840 took Britain from the reign of George II to the reign of Victoria, from the age of price riots to the age of the Chartists. Those years, by many more accounts than Francis Place's, saw the creation of a political framework which made large-scale parliamentary democracy possible-and sometimes even effective-in Britain. In the process, important changes occurred in the ways that ordinary Britons acted together on their grievances and interests. The appeal to a powerful patron, for example, became a less prominent way of doing political business, while some form of direct demand to national authorities became more common. When the eighteenthcentury English made a public statement of their approval or disapproval of a person or a policy, they frequently did so by staging some sort of street theater: Rough Music, effigies, burlesque costumes, mocking songs, and pantomimes all played their part. By the second quarter of the nineteenth century, these forms of action had become relatively rare. But it had become quite a regular practice to form a special-purpose association, to hold public meetings in its name, to issue demands and petitions on behalf of its membership.

$\therefore$ During the same period, the demonstration (in the narrow sense of a pre-planned assembly in a symbolically significani public space by a group of people who visibly identified themselves with a specific demand or complaint) became a much more widespread way of showing the strength and determination behind a given position in a public controversy. Strikes (or, to be faithful to the language and reality of the time, turn- 
outs) likewise came into wider use. These are only some of the many alterations in the ways that ordinary people acted together on their interests. Although the specific timing and particular path of change varied from one place to another, similar transformations occurred through much of the western world during the eighteenth and nineteenth centuries. They brought into being much of the pattern of collective action with which westerners still work today.

\section{An Approach to Explaining the Changes}

The research sketched here traces those transformations in one crucial place, London, and makes some preliminary attempts to explain them. The tracing emphasizes the changing geography of "contentious gatherings" in the city over the period from 1758 to 1834. The explaining is deliberately preliminary and incomplete: it consists of examining how the redistribution of economic activity, administrative activity, and residence in London affected the spatial patterns of routine gatherings, and then attempting to determine the influence of these changes in economic, administrative, and residential structure and in routine gatherings on alterations in the geography of contention.

"Contention," in this context, is the making of claims which bear on other people's interests. A "contentious gathering" is an occasion on which several people assemble and visibly make a claim which would, if realized, affect the interests of some other person(s). As a practical matter, we are limiting attention to gatherings of this sort which occur in places accessible to the public and which involve at least one group of ten or more persons outside the government. Over the period from 1758 to 1834, some examples of events which frequently qualify as contentious gatherings are electoral rallies, fights between hunters and game wardens, meetings which send petitions to Parliament, and public ceremonies at which the crowd jeers or cheers an official.

The definitions are abstract and arbitrary. Yet they serve to single out occasions on which people act together publicly, and they include the vast bulk of the events which historians have in mind when they use the words "protest," "riot," "disorder," or "mass action." Contentious gatherings also include a number of quieter, more clearly legal, assemblies-meetings, rallies, and other gatherings which neither historians nor the authorities of the time could have called riots, yet which were often similar in structure to the so-called riots, and which likewise pressed claims affecting other people's interests.

These mildly unconventional definitions reflect a specific point of view. For the purpose of this discussion, two elements of that viewpoint deserve attention. The first is that words such as "riot" and disorder" are obstacles to sound historical analysis, for all their use by contemporary observers. They are elite words, author- ities' words, words which judge an action as incoherent, improper, and worthy of repression. Their use condemns us, as later analysts of collective action, to ignore the similarities of events, such as the meeting broken up by the authorities and the meeting protected by the authorities, which actually have a great deal in common. If our topic is how ordinary people acted on their interests and grievances, we need a vocabulary which gives room to those interests and grievances. Hence the vocabulary of contention and contentious gatherings.

The second element is an hypothesis. It is that at any given point in time a particular group of people have. available to them only a very limited number of alternative means of acting on their interests and grievances, that each of those means tends to have a well-defined form which is known to the potential participants in contentious actions, that in the event of an opportunity to act or a threat to its interests any group does a rough matching of its available means of action with likely outcomes and thus chooses whether and how to act, and that the events which authorities label "riots," or "protests," and the like characteristically begin with just such well-defined forms of action. Thus in the middle of the eighteenth century English villagers commonly knew how to stage Rough Music, how to call a local assembly to petition the king, how to seize hoarded grain, and so on through a limited number of alternative forms of action, but did not know how to demonstrate, how to strike, or even how to hold an electoral rally. A convenient metaphor for that set of known means of contention is a repertoire. The existing repertoire of contention, goes the hypothesis, strongly limits the involvement of any particular group in the contention of its time. It follows that changes in the prevailing repertoire, for example, the disappearance of one form of action or the increasing availability of another, have autonomous effects on the intensity and form of involvement of different groups in contention.

That hypothesis brings us back to the main point of this research. For the prevailing English repertoire of contention changed importantly between 1750 and 1840. The set of means of contention which still prevails through most of the western world today (the strike and the demonstration are the obvious examples) first came to prominence in England during that period. London appears to have played a leading role in the transformation of contention: serving as the setting of the innovative popular politics of John Wilkes and Lord George Gordon, providing the models for large-scale workers' movements via the dockers and the Spitalfields weavers, and so on.

Why and how did these changes happen? Some likely pieces of the explanation are the rise of special-purpose associations (including firms, clubs, parties, and labor unions) as political and economic actors; the creation of a national electorate and the concomitant growth of electoral politics; the waning of communal groups (including villages, craft guilds, and religious com- 
munities) as the loci of shared interests and the vehicles of collective action; the concentration of capital and the coordinate increase in the scale of production; the growing power of the national state with respect to other sets of authorities. Another likely influence is the alteration in the internal structure of communities, especially big cities. The research described here focuses on that alteration, as it worked itself out in the great city of London from 1758 to 1834.

The point is not to reduce the massive changes in popular action to effects of changing urban structure. It is, rather, to specify with what changes in urban structure, if any, the shifis in contention were closely correlated and to begin the close examination of the relationship between the two, with the long-run hope of understanding to what extent the changes in urban structure shaped the changes in contention. It seems likely, for example, that the increasing segregation of an elite western side of London, equipped with large parks and promenades, from an increasingly working-class eastern side also segregated the customary meetingplaces of workers from those of the well-to-do and that this rising segregation altered the character of meetings and confrontations between the two groups.

At least that is one interpretation of the available evidence. As D.A. Reeder says:

The migration of the aristocracy into the western suburbs explains in part why those citizens of London interested in establishing a social position chose to live in the districts beyond the west end of town. By 1831 as many as $\mathbf{2 0}$ per cent of all occupied males over 20 living in Paddington and Kensington and 14 per cent of those living in Hammersmith were listed in the census returns as capitalists, merchants, and professional men."

Speaking of the later eighteenth century, George Rudé concludes that ". . . a growing gulf was drawn between the eastern and western districts of London. Where, earlier, citizens had sought their recreations and country retreats almost indiscriminately either east or west, the east was now becoming more and more the sole preserve of the industrious and poor and the west that of the fashionable and rich." And John Stevenson has said explicitly that "The capital's fragmentation into a number of distinct political groupings was one of the most important developments during the course of the nineteenth century. "6 In one form or another, then, the general idea of increasing class segregation of east from west is a commonplace of London's urban historiography.

Another change which has attracted less attention was in gathering places. By 1820 the chief locations for public meetings and for asemblies of special-purpose associations were taverns and coffeehouses. In another of his diatribes against popular politics (this one from 1812), Southey declared that "The weekly epistles of the apostles of sedition are read aloud in tap-rooms and pot-houses to believing auditors, listening greedily when they are told that their rulers fatten upon the grains ex- tracted from their blood and sinews; that they are cheated, oppressed, and plundered; that their wives and children are wanting bread, because a corrupt majority in parliament persists in carrying on a war which there was no cause for beginning, and to which there can be no end in view." We need not share Southey's sentiments to think that drinking-places played a significant part in the contention of the time; in particular, the rise of the meeting and the proliferation of public houses surely had some connection. Since broadly similar changes were occurring in many other cities, a careful examination of London's experience will cast light on an important general transformation-one whose consequences are still with us today. If it turns out that changes in the structure of the city as such had little to do with the alterations in concentration, then that, too, will be a significant discovery.

\section{Urban Structure as an Influence on Contention}

Now, "urban structure" is a complicated matter. We can simplify it by breaking it into three elements and the relationship among them:

a territory, which in this case is London;

a population, which is the resident population of London;

a set of activities, which is the production, distribution, and consumption of all sorts of goods and services anywhere in London.

Obviously each of these has its own structure; for example, the territory is differentiated into various kinds of buildings and spaces, and the population has a characteristic distribution by age and sex. In addition, each pair of elements has a structure: the population is distributed over the territory unevenly, different segments of the population are differentially involved in the city's major activities, and so on. "Urban structure" includes all these aspects of the city.

In this research, we pay attention to many different aspects of urban structure, but we stress the territorial distribution of population and of activities. We have several reasons for that emphasis. The first reason is that the spatial reorganization and expansion of the eighteenth-century city ought to have affected the pattern of contention. In principle, we might reasonably expect the increasing segregation of workers from the rest of the population, and the declining division of the city into households and neighborhoods grouping together all members of a single trade from masters to servants, to have weakened trade-wide solidarities and to have strengthened solidarity on the basis of class. In principle, we might also expect the sharpening division between an impoverished East and a wealthy West to have diminished the variety of the people frequenting any particular street, square, inn, or other gathering place, to have intensified the emotional and symbolic impact of a foray into "someone else's" territory, and 
to have promoted an increased segregation of different types of contentious gatherings from each other. It is reasonable to suppose, for example, that the standard of aggrieved workers, from Mansion House to Charing Cross and thence (depending on the issue and the target of the workers' complaints) either to St. James' Palace or to Parliament, became a greater and riskier adventure as the class differences among Westminster, the West End, and the City increased. Whether these reasonable expectations actually hold up under close scrutiny-and if not, why not-is one of the major questions raised by the research we have begun.

Spatial structure is also an attractive starting point, because some features of it are fairly easy to specify. and observe. It is easier, for instance, to detect the location of the average contentious gathering than it is to search out the class origins of the participants. Furthermore, locational patterns often provide clues as to the participants and issues involved. (George Rude's famous analyses of conflicts in London and Paris have capitalized repeatedly on that advantage.) Finally, the straightforward mapping of the action of a single event or of an important series of events leads easily and immediately into significant causal inquiries: why and how people got there,what they did next, what started and stopped the action, and so on. Without claiming for an instant that spatial structure "causes" contention, then, we can reasonably claim that an analysis of the relationships between the city's overall spatial structure and the geography of contention is likely to yield valuable returns.

With these pieces in place, we can restate the major aims of the research. They are to describe the overall changes in the character of contentious gatherings in London from the 1750 s to the 1830 s; to trace precisely the changing geography of those contentious gatherings; to infer from that and other evidence what alterations in the prevailing repertoires of contention $\alpha c$ curred over the period; to identify, in a preliminary way, such connections as exist between the changing character, geography, and repertoires of contention and the shifting distributions of population and activities within the city, and to use the results of that analysis, including the specification of changes in contention which the city's changing spatial structure cannot explain, to reformulate existing ideas concerning contention.

\section{Connections with Previous Work}

The research touches two separate literatures: that on collective action in general, and that on Britain, and especially London, in the eighteenth and nineteenth centuries. The relationship of this project to both literatures is peculiar. Let us think first about the literature of collective action. Precisely because the disagreement in the literature extends to the very categories within which inquiry is framed, work on the subject proceeds under a great variety of names: social movements, conflict, collective behavior, political processes, protest, and political participation, as well as collective action itself. To emphasize collective action as the common ground of these phenomena is to single out the ways people act together on behalf of shared interests. We prefer that definition of the problem both because it is broad enough to inciude most of the phenomena scholars have studied under the other headings and because it calls attention to the connections between routine pursuit of interests and the extraordinary bursts of activity which authorities call riots, rebellions, and social movements.

Our approach to collective action employs two simple models: a polity model, which portrays the interactions of various sorts of interest groups with each other and with governments, and a mobilization model, which sketches the conditions under which people who share an interest act together, or fail to act, in response to the costs and benefits entailed by the different available courses of collective action. We think of the available courses of action, in turn, as being limited by the resources the groups in question have already accumulated, by the repression and facilitation being extended to them by other groups, and by the repertoire of means of action with which the group is already familiar. These ideas may look self-evident. Yet the great bulk of the literature on the subject takes either of two very different tacks, either inferring action directly from interests, while minimizing the costs of organization, of repression, and so on, or attributing action to shared states of mind: anger, frenzy, frustration, and the like. Our work breaks with those two dominant traditions.

As for the literature on the history of London and Britain, our general topic is commonplace, our way of defining the problem is unusual, and our manner of approaching the evidence is unique. Many historians, and a number of nonhistorians, have studied different forms of conflict in the period of 1758 to the 1830s: Darvall, Mather, Hamburger, Thompson, Rudé, and Hammond are only some of the obvious names. London has come in for particular attention, among other reasons, because of the color and liveliness of London's conflicts, because at the time and later many observers have thought that London's movements came close to having a revolutionary potential at one point or another, and because it has seemed that the resolution (or repression) of the period's protests set the pattern of subsequent British politics and became a model of relatively peaceful problem-solving for the western world as a whole. All of these are commonplaces.

To define the problem as accounting for the geography of contention, however, is more than giving a new name to old questions. Among recent scholars familiar to us, only John Stevenson and George Rudé have shown much interest in our version of the problem: Stevenson asking how public order was imposed or maintained in a massive, changing metropolis, Rudé 
seeking to relate the spatial patterns of riots and protests to the interests of established groups in the city. Dealing with the geography of contention broadens the problem by bringing in a much wider range of events than interest Stevenson or Rudé (thus making it possible, we think, to relate the events which do interest other historians more securely to their context) and by seeking deliberately to connect the geography of contention with the geography of routine congregation in the city.

This research on Loridon grew from, and overlaps with, an investigation of contention in Great Britain as a whole. For the brief but critical period 1828 to 1834 , we are examining contention in all parts of the country and undertaking special investigations of such major events as the campaign for Catholic Emancipation, the Swing Rebellion, and mobilization for Reform. The seven years under study are yielding massive documentation concerning an estimated 5,000 contentious gatherings and their settings in England, Scotland, and Wales.

The research falls under these main headings:

1. documenting contentious gatherings, 1758-1834;

2. describing the redistribution of economic activity, administrative activity, and population distribution, 1758-1834;

3. describing changes in the geography and organization of routine assemblies, 1758-1834;

4. relating the changes in routine assemblies to the changes in economic, administrative, and demographic structure;

5. relating the alterations in contentious gatherings to the changes in economic, administrative, and demographic structure, and to the shifts in routine assemblies; and

6. singling out three or four small areas for intensive analysis.

\section{Documenting contentious gatherings, 1758-1834.}

A glance at the three small catalogs of events in the appendixes will give an idea of what the material already on hand tells us. The first is a list of all contentious gatherings in London mentioned by the Annual Register or Gentleman's Magazine for 1765, 1766, and 1774. The second is our sample of London events for June 1828. The third is an enumeration of contentious gatherings and routine assemblies in four areas of London-St. Marylebone, Westminster, Southwark, and the City-during the whole of 1828. A comparison of the three catalogs immediately establishes that there is something to explain. The eighteenth-century events include a high proportion of food riots, of trade disputes, and of authorized public gatherings during which people began to make contentious claims. The nineteenthcentury gatherings include, among other things, a great many scheduled meetings of associations and public assemblies.

Some of the apparent differences between the two periods undoubtedly stem from the sources consulted for this preliminary enumeration: only a monthly and an annual periodical for the eighteenth-century events, a barrage of publications (some of them daily) for the nineteenth century. That more intense search of the 1828 sources (exactly the sort of search we are now undertaking for our entire period from 1758 on) surely accounts for the much greater number of events identified for 1828 than for the average year of the 1760 s or 1770s. But an examination of the relevant archives (notably the State Papers for the eighteenth century, the Home Office Papers for the nineteenth) confirms that a shift toward associations and meetings as the contexts of contention did, indeed, occur.

The work under this heading breaks into several segments: further enumeration of contentious gatherings, search for additional documentation concerning those gatherings, coding and editing the descriptions of those gatherings in machine-readable form, and analyzing and mapping changes in the characteristics of those gatherings. We have selected a total of twenty years (including the relevant years between 1758 and 1820 for which we have already done preliminary readings of the Gentleman's Magazine and the Annual Register) spread over the period from 1758 to 1834 for close study. In those years, we are checking our previous work on Gentleman's and the Register, doing a systematic reading of the London Chronicle (which also went by the name of Commercial Chronicle and London Packet at various stages of its career), attempting some systematic checking of those sources against the metropolitan dailies (c.g., the Times) when they begin appearing in the 1780 s, and undertaking further crosschecking of the biases in those sources. For the period from 1828 to 1834 , we are extracting the relevant events from the files of our general study of Great Britain.

The "London" in question is actually at least three geographical units: (1) the southeast counties, Middlesex, Surrey, Sussex, and Kent; (2) the built-up area, according to the best apporoximation we can manage (for the period after 1801, for example, Karl Gustav Grytzell's County of London: Population Changes, 1801-1901 will be a valuable guide, and (3) the City, Westminster, Southwark, plus the set of boroughs which were thickly populated at various points in time. London's incessant expansion between 1758 and 1834 will require us to consider a larger and larger city as time goes on. The technical problems involved, however, will be less formidable than they seem, because our coding procedures pinpoint each event precisely in terms of the British National grid-square coordinates system, thereby permitting us to change definitions after the fact.

Map 1 is a computer reproduction of the four-county area noted above. We have finer de: : iled versions of the individual counties, and the grouping as a whole, for 


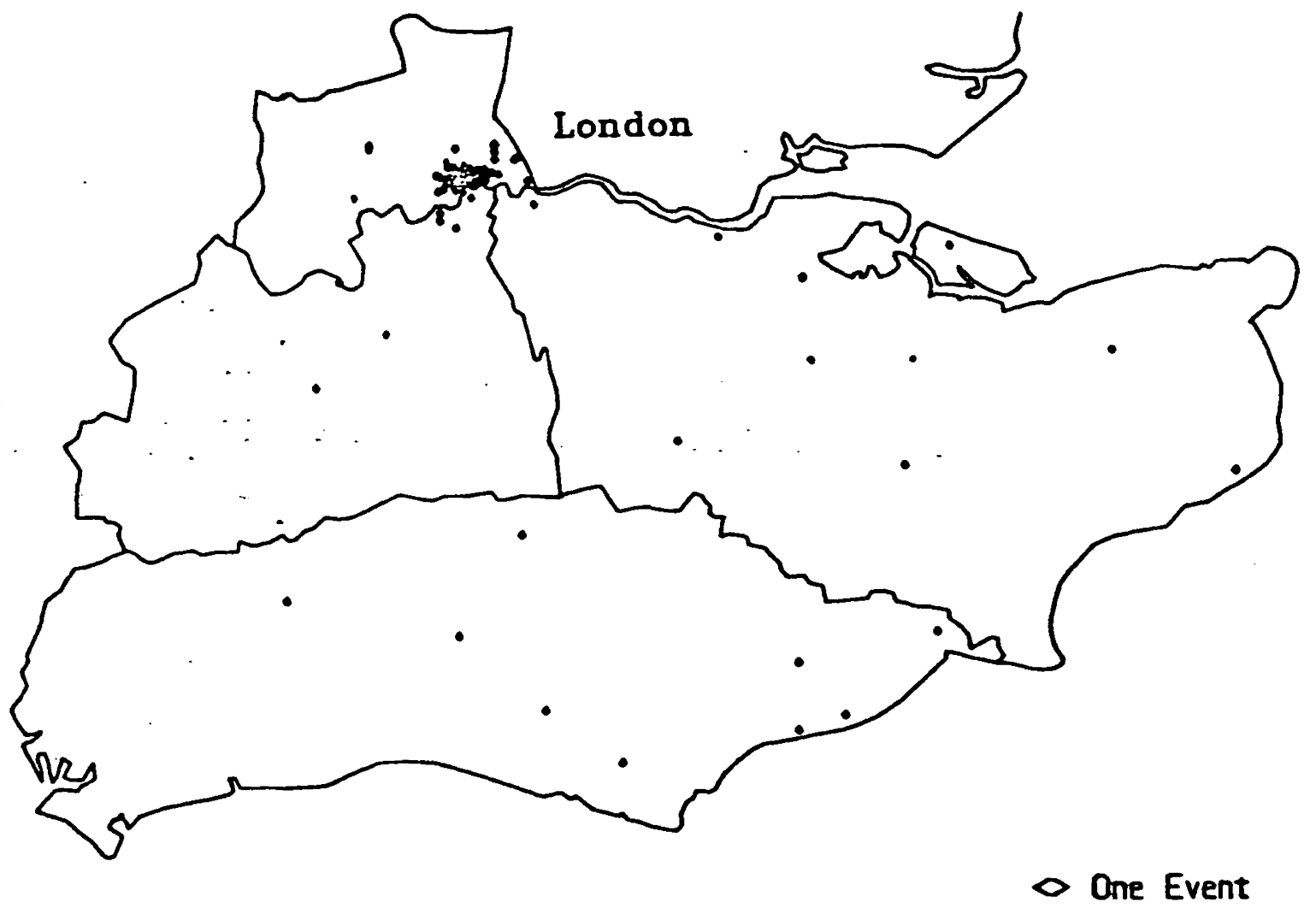

Map 1.-Contentious gatherings in the London area: 1828

use when needed. This four-county presentation has some interesting analytical mapping possibilities. Pictured are all the contentious gatherings of 1828 within the four-county region. The gatherings concentrate in the built-up urban area. The distribution of 1828 contrasts with the more rural location of gatherings in 1830 , when the laborers' revolt was occurring in London's hinterland.

Map 2 provides a sample of the occupational information available; it locates the textile establishments listed in Kent's directory for 1768. Textiles show a remarkable citywide distribution, in contrast to the more centralized northwest concentration of the 1830 s. Over the intervening years, we can watch to see which were the first trades to set up in the northwest, and from what areas the other trades followed. We can also watch who took their places as they moved. Although the data are simple, they invite a close analysis of the city's changing economic geography.

When we have enough information to overlay the two types of data, business and contention, we begin to see some of the relationships between the economic makeup of a particular area and its citizens' collective action. Is there, for example, a prescribed route taken by groups of people involved in the shipping trades when they present a petition to the king, say, from the East End to St. James' Palace? We have some indications that there is. Are the gathering places of linen-drapers close to their places of business? Does the makeup of an area's businesses affect the types and participants in the area's col- lective action? In each case, we expect the answer to be yes. But a "no" would bikewise raise new and stimulating questions.

Further documentation of the enumerated events comes from contemporary diaries and biographies, from published historical works, and from a variety of archives. Among the archives, the highest priority goes to the State Papers, Home Office Papers, and Metropolitan Police Papers in the Public Record Office, London. The Place Papers and Chadwick Papers, among others, at the British Library are useful for context. In the Clements Library, University of Michigan, the Grenville, Shelburne, and Sydney Papers promise to yield relevant information.

Once the dossier for each event is complete, we prepare a machine-readable description of the event, using the procedures we have developed for the study of Great Britain as a whole. Because of the way: we have designed those procedures, the coded events are immediately available for tabulating and automatic mapping. For the period from 1828 to 1834 , the use of the same format facilitates the comparison between London events and those from the rest of Great Britain. The results of this first phase will, therefore, be a set of analyses of changes in the general characteristics of London's contentious gatherings from 1758 to 1834, a set of annual maps of the locations of different types of contentious gatherings within Middlesex and Surrey, including an analysis of the correlates of different characteristics of contentious gatherings (e.g., the rela- 


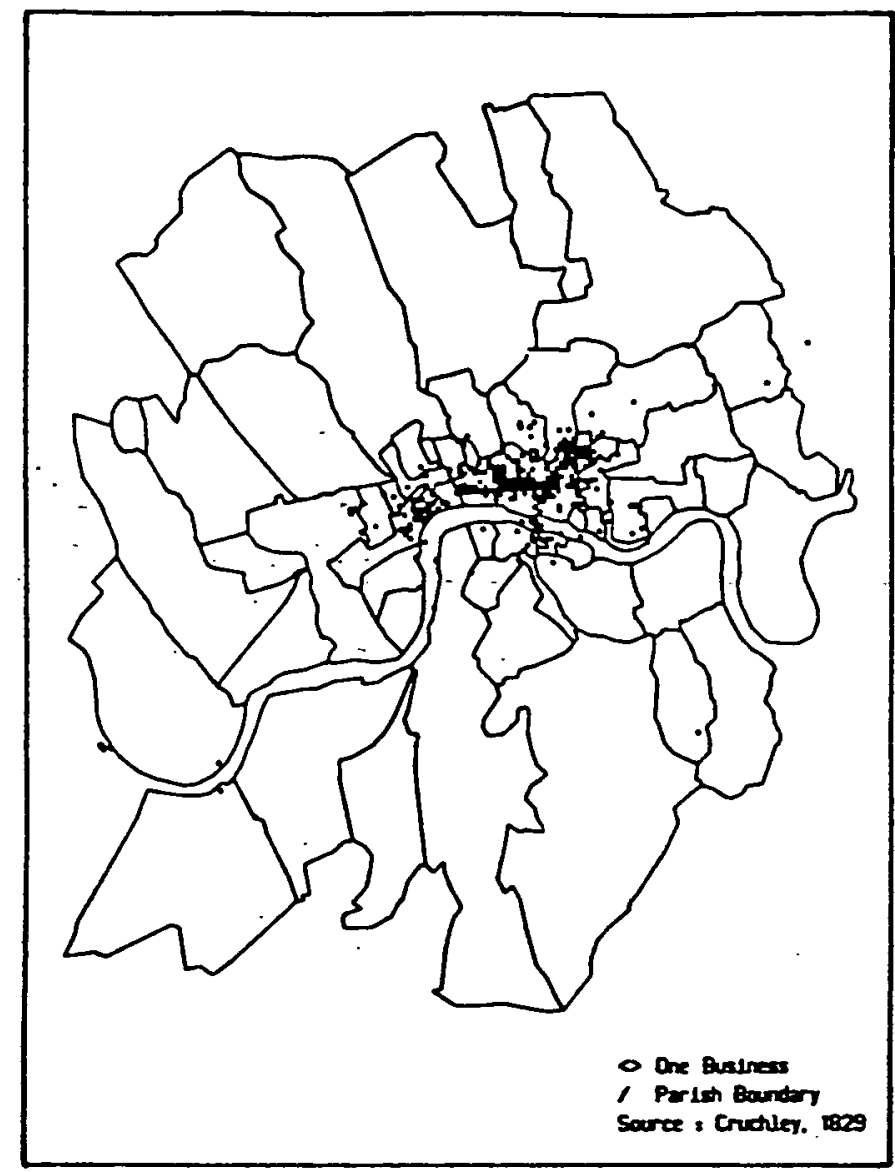

Map 2.-The textiles industry: London, 1768

tionships among working-class participation, attacks on property, and location of the event) at different points in time, and a comparison of London events with those from the rest of Great Britain in 1828 to 1834.

We can describe the other main headings of the research program more succinctly.

2. Describing the redistribution of economic activity, administrative activity, and population distribution, 1758-1834.

Here we are undertaking a modest effort, in hopes of undertaking something more serious later on. It is to use the available maps, atlases, and scholarly studies to produce a decade-by-decade series of sketches of the following:

a. the basic grid of streets and squares;

b. built-up area, with some general indications of population densities and predominant types of structures;

c. locations of major public buildings and monuments, with some indication of their current political and symbolic significance;

d. principal centers of craft, industrial, and commercial activity;

e. general characteristics of the population.

For purposes of this description we will speak of a "decade-by-decade" sketch, but we may well shift the years involved to capitalize on the availability of major sources such as the 1801 census and the Lysons volumes. How complete the collection of local information will be depends on sources we are still in the process of identifying and abstracting; the finished catalog will be, in itself, a contribution to further research on London. The material we have identified so far makes it clear that a preliminary series of sketches is feasible. Consider, for example, these two summaries of information contained in Daniel Lysons, The Environs of London . . . Towns, Villages and Hamlets within Twelve Miles of that Capital, published in 1810:

St. George in the East: Made a distinct parish by Parliament in 1727; formerly part of Stepney. An eastern suburb. Bounded by St. Mary Whitechapel, St. John Wapping and Ratcliff and MileEnd Old Town. Land unoccupied by buildings on north side only. In 1802, the London docks (fortyeight acres) were begun; they were first used in 1805. Many cranes and warehouses. Inhabitants are ropemakers and rigging makers for ships. Large soap manufacture on Old Gravel Lane. Many Danish and Swedish inhabitants. Population increase was great within the last thirty years: 3,700 houses in 1794, 4,029 occupied houses and another 119 unused in 1801. Many small cottages-3,800 the current number-in the upper part of the parish. There are school houses for boys and girls, an almshouse, and a medical institution.

Hackney. Northeast side of London. It extends from Cambridge Heath to Stamford Hill, with a circumference of eleven miles. (A detailed enumeration of boundaries follows, as well as a list of major roads.) 3,227 acres, 580 arable, 1,570 under marsh, 110 occupied by market gardens, 40 by nursery men, and 170 in brick fields. Grassland is occupied by cowkeepers. Vast quantities of brick and tile are made in the parish. Temple Mills used to refine lead. Large silk mills employ between 600 and 700 women. The area is the site of many old mansions. Well Street and Shackelwell are popular districts. There was a college of Protestant dissenters, since torn down, in the 1780s; there is still an academy for dissenting ministers. There is a Jewish burial ground. The area had 983 households in 1756, 1,212 in 1779, 1,500 in 1789 . 1,600 in 1793, 2,050 in 1801 (when 84 houses were unoccupied); the 1801 population was 12,730 . (The account includes a list of schools, almshouses and hospitals.)

Of course, we have to compare and verify different descriptions of the same area as much as possible. The published volumes of the Survey of London are especially valuable in this regard. Although the descriptions in the older sources are imprecise, they are perfectly suitable for coding. They also provide an agenda 
for further exploration, for example, to locate the "Catholic, Methodist, and Independent meeting houses" in St. George in the East. Other surveys in the same style include John Entick's History and Survey of London, Westminster, Southwark and Places Adjacent (4 volumes, 1766) and Edward W. Brayley's London and Middlesex . . . Survey (5 volumes, 1810). Our initial collection of information about urban structure and routine gatherings uses parishes and wards as its units of observation. That is, however, no more than a convenience since all data are geocoded using the British Ordnance Survey's National Grid reference system. A resolution of 100 meters is used, making the grid references six-digit numbers. Standardization of geocoding allows cross-referencing of locational data with digitized outlines of wards, parishes, and other administrative units. Point-in-polygon-algorithms can then be used to recode the discrete data by any area units desired. Computer programs to achieve this recoding are under development.

3. Describing changes in the geography and organization of routine assemblies, 1758-1834.

For the present, this is also a modest effort. We are collating three bodies of material:

a. reports of surveillance in the archives mentioned earlier, especially the State Papers and the Home Office Papers;

b. compilations concerning gathering-places such as de Castro's manuscript dictionary of London Taverns (Guildhall Library);

c. information in the same periodicals we are consulting for the enumeration of contentious gatherings: Gentleman's Magazine, the Annual Register, the London Chronicle, and, for the later period, the Times and the Morning Chronicle (for the moment, Hansard, Mirror of Parliament, and Votes and Proceedings do not look like useful sources for this purpose).

The basic idea is similar to that for the redistribution of economic, administrative, and demographic activity: to prepare decade-by-decade sketches of the principal locations and occasions which brought together members of specific trades, specific political groups, and other sets of people who sometimes participated in contentious gatherings.

\section{Relating the changes in routine assemblies to the changes in economic, administrative, and demographic structure.}

Given the incomplete evidence we are going to collect under the two previous headings, this effort cannot be terribly ambitious, either. The central idea is obvious: it is to compare the decade-by-decade sketches of population and activity distributions with those of routine assemblies, to see whether the common-sense correlations (e.g., of working-class gathering places with working-class residences) hold up, and to consider whether major changes in the organization of different interest groups correlated with changes in the relationships among their places of residence, work, and assembly. For example, it looks as though the rise of political and working-class associations toward 1830 produced a great increase in big meetings in such locations as Southwark's Rotunda, which means in turn that many people left their places of work and residence and traveled across the city to meet their fellows. That pattern of mobilization seems quite different from the one by which John Wilkes and Lord George Gordon gor together their giant marches of the 1760s and 1770 s.

5. Relating the alterations in contentious gatherings to the changes in economic, administrative, and demographic structure, and to the shifts in routine assemblies.

Here we can be somewhat more ambitious than in the two previous cases, because the documentation concerning the contentious gatherings themselves will contain information about these relationships. We can, for example, ask how frequently, and in what way, authorized public celebrations and spectacles such as Lord Mayor's Day, the King's birthday, Guy Fawkes' Day, hangings, and other public punishments figured in the contentious gatherings of different periods; our preliminary idea is that they became much less important as time went on. Given the decade-by-decade sketches of urban structure and routine assemblies, we can also determine how much of the changing geography of contentious gatherings was readily predictable from the spatial reorganization of the city, and at what points in time the most important alterations occurred. We can examine which participants in contentious gatherings found themselves in alien territory at various points in time; is it true, for instance, that with the increasing class segregation of the city, more and more workers' marches and demonstrations took them away from their home bases and into enemy territory? Were the shady squares of the West End out of reach? Did the changing strategies of policing and crowd control reflect the authorities' awareness of these sorts of alterations?

6. Singling out three or four small areas for intensive analysis.

We plan to choose three or four small areas, parishes, wards, or something else, for particular study. The ideal area would have the following characteristics:

a. good, continuous records of lind use, economic activity, administrative structure, and population distribution from 1758 to 1834;

b. competent local histories already published, or available in manuscript, over the entire period;

c. a significant level of local contention over some portion of the period:

d. some evidence shedding light on the local structure of power, mobilization patterns, routine assemblies, and their changes over the period. 
Overall, the three or four areas should be of contrasting types with respect to urban structure. For example, sections of Westminster, Southwark, and the City would, sources permitting, lend themselves to valuable comparisons. We plan to choose the three or four small areas which best fit all these criteria, to collate and map the available information street by street, to undertake close monographic studies of the interplay of urban structure, routine assemblies, and contentious gatherings in each one, then to make careful comparisons among them, both for their own sakes and for the purpose of generating new ideas about patterns of variation over the whole metropolis of London.

Some parts of our procedures and evidence will be hard to use outside the University of Michigan, while others will transfer easily elsewhere. At the hard end of the range lies our storage of information on contentious gatherings in the database management system MICRO, an efficient organizer of very large files maintained by the university and extremely difficult to export. At the easy end we find self-contained standard files such as our machine-readable transcriptions of trade directories. To the extent possible, we will make welldocumented copies of materials at the easy end of the scale readily available to other researchers for use in their own settings. At the hard end of the scale, we invite collaboration with researchers who have the time and means to work with us in Ann Arbor. Although our chief reason for undertaking this research is to deepen our understanding of the relationship between conflict and changing urban organization, we will be delighted if the materials and procedures of the inquiry make it possible for our colleagues to pursue other important problems concerning the history and social structure of London.

\section{APPENDIX A}

A Catalog of Contentious Gatherings in London, 1765, 1766, and 1774

765-01-10-01 On Thursday the King opened Parliament, and a body of some thousand weavers marched upon the building to present a petition asking for a prohibition on foreign silks.

765-05-14-01 A large mob of weavers marched in procession from Spitalfields to St. James carrying a black flag with the intention of presenting a petition, setting forth their distressed condition, to the King.

765-05-16-01 Eight thousand Spitalfield's weavers assembled in Murfields to march again to St. James Palace. On this occasion the guards were drawn out and effected the correct measure, as no violence occurred.

765-05-17-01 The weavers again assembled and marched to St. James without violence, but on their return to Spitalfields they beset the house of some silk merchants and broke the windows. Upon the arrival of the civil and military powers the rioters dispersed.

765-05-17-02 On the same day, a crowd gathered outside the residence of the Duke of Bedford in London and were trampled by the horse troops who had been called out to disperse them.

765-12-04-01 A numerous meeting of merchants trading with North America was held in London. They met to discuss a remedy to the recent differences between Britain and the colonies. A deputation was appointed to seek the ministry's suppor for an application to Parliament.

765-12-23-01 After the election in Southwark the supporters of Henry Thale Esq. paraded through the town. The cavalcade was made up of horseman and bands of music.

766-05-19-01 Upwards of 500 fellows assembled in a riotous manner near Gray's Inn Lane, London; they insulted several people and extorted money from others under the pretense of being distressed weavers.

766-06-00-01 Early in June the Haymakers assembled at the Royal Exchange to the number of 440 . They prayed for relief because the heavy rains had prevented them from getting work; a collection was taken up for them.

766-07-13-01 While a Methodist preacher was presenting his sermon in the ruins of St. Giles in London, he was attacked by a mob, who broke his arm and fractured his skull. The cause of the attack was said to be his statements against the church of Rome.

774-07-28-01 A meeting of 500 Middlesex freeholders was held and a resolution passed supporting their worthy member John Wilkes.

774-09-26-01 A meeting of freeholders was held at Mile-End, London, for the purpose of nominating persons to represent the county of Middlesex. Mr. S. Glynn and John Wilkes were unanimously approved.

774-10-06-01 The polling for Lord Mayor took place; upon John Wilkes being declared the winner, the horses were taken from his coach and it was drawn through the streets by the populace.

\section{APPENDIX B}

A Catalog of Contentious Gatherings in London, June 1828

828-06-02-01 In London, the freemen of Durham, residing in London, met, resolving to continue their support of Sir Henry Harding, the Member of Parliament from Durham.

828-06-02-02 A disturbance occurred at the British Gallery, Pall-Mall, London, when an officer, who had been entrusted with maintaining order among a line of coaches, was run down by an angry coachman. A mob pursued the driver, throwing mud and stones.

828-06-02-03 An Association of British Catholics met at Freemason's Tavern, London, to receive the report of a committee which was reworking the rules of the Association; a vote of thanks was passed to the Duke of Sussex and the Duke of Norfolk.

828-06-03-01 A meeting of Durham Freeholders, residing in London, was beld in the Three Tuns Tavern. London, to nominate a candidate for the upcoming election.

828-06-06-02 An open vestry meeting, attended by parishioners, was held in St. Paul's Covent Garden, London. Attempts were made to end the dissension over select vestries that had so 
long divided the Parish.

828-06-08-01 A brawl occurred in Stepney. Middlesex, between several hundred Irishmen, who, on their way home, attacked those who came across their path. Sixteen Irishmen were finally arrested.

828-06-09-01 A meeting of British Catholics was held in London's Freemason Hall to discuss the Catholic Emancipation issue currently before Parliament.

828-06-10-01 The parishioners of St. James' Parish met in the Public Rooms, Brewer Street, Golden Square, London, to consider parish affairs and the poor administration of their select vestry.

828-06-12-01 The East India Company gave a dinner in support of Lord Melville at the Albion Tavern, London.

828-06-14-01, The British Catholic Association met in London's Freemason Tavern to consider rules and regulations of the association.

828-06-16-01 A disturbance occurred in Sydney Street, London, when a mob, on discovering that a woman had attempted to hang her own daughter, broke the windows in her house.

828-06-18-02 At the celebration of the Anniversary of Waterloo in London, the populace thronged the river shores and cheered the Duke of Wellington upon his arrival.

828-06-18-03 A dinner was held in London's Freemason's Tavern to celebrate the repeal of the Test and Corporation Acts; the Duke of Sussex was thanked for his efforts in the repeal.

828-06-21-01 A meeting, to establish a seminary for educating the youth of the metropolis and imparting religious education, was held in London; the Duke of Wellington was loudly cheered.

828-06-25-01 Deputies of Protestant Dissenters met in the King's Head Tavern, London. A petition, against clauses in a Bill that would give unconstitutional power to select vestries, was agreed to.

828-06-29-01 An affray between English and Irish haymakers took place in Wambly, Middlesex; in the course of their struggle one man was murdered.

828-06-00-02 Welsh Calvinist Methodists met at Jewin Crescent, London, to petition Parliament in favor of Catholic claims.

828-06-00-04 A meeting of the Congregation of the Calvinist's Worship was held in London. It was agreed that a petition supporting Catholic Emancipation should be presented to Parliament.

828-06-00-06 Protestant Dissenters met in St. George's in the East, Middlesex, and petitioned Parliament against Catholic emancipation.

Sample Contentions Gatherings and Routine Assemblies for Four Areas in 1828

1. Marylebone: Contentious Gatherings

828-02-00-15 A group of Protestant Dissenters assembled at their place of worship in Marshall Street, Golden Square, and resolved to petition Parliament for repeal of the Test and Corporation Acts.

828-02-00-76 Another anti-Test and Corporation Acts petition resulted from a meeting of Protestant Dissenters of the Independent Denomination at Paddington Chapel.
828-02-20-01 Approximately 1,500 parishioners gathered at the Bazaar, in King Street, Portmansquare, to discuss oppressive parish rates and the related issue of the Select Vestry. Mr. Rawford, M.P., chaired the meeting. It was determined that unreasonable parish taxes could be attributed directly to the Select Vestry system. A motion was carried to petition Parliament in favor of opening the St. Marylebone vestry.

Marylebone: Routine Assemblies

The vestry called a meeting (one of a regular series) to let ash contracts and for cleaning the streets. The meeting is set for 9 February.

A fure occurs in a dwelling house and a crowd gathers to watch. This is a common occurrence throughout the area and time period.

2. Southwark: Contentious Gatherings

828-02-00-42 Assembling at their Meeting-house in Union Street, Protestant Dissenters agreed to petition Parliament for repeal of the Test and Corporation Acts.

828-04-00-06 At the Surrey Street Chapel, Blackfriars, a group of Protestant Dissenters determined to send an anti-Test and Corporation Acts petition to Parliament.

Southwark: Routine Assemblies

On 28 January the vestry of St. Savior's had its regular vestry meeting to discuss parish business and set new rates.

At an address on Blackfriars Road a new series of Unitarian lectures is beginning and the streets are crowded with people awaiting the opening of the doors to the lecture room.

\section{Westminster: Contentious Gatherings}

828-10-04-02 A riot occurred in a brothel on Frith Street, Soho Square, when a man named Goddard attempted to remove his wife and daughter from their place of employment. Goddard and a friend were attacked by about twelve prostitutes. Constables arrested everyone involved in the fray.

Westminster: Routine Assemblies

On 8 February a deputation of Dissenters visited the Duke of Wellington to discuss the fate of the Test and Corporation Acts bill now before Parliament. This is a series of deputations and delegations that visit the government offices weekly.

When Parliament is in session, there are regular gatherings of crowds to gain seats to hear the debates. These crowds begin gathering in the morning outside Commons and clog the streets until the opening of the gallery doors.

There is a "Grand Masonic Festival" in honor of the Duke of Sussex held at the Freemason's Tavern on Monday, 28 January. The tavern also plays host to a number of other similar functions, such as Surgical Society meetings and Butchers Charitable Institution meetings.

\section{St. Poul's, Covent Garden: Contentious Gatherings}

828-01-10-02 At a "noisy and uproarious" parish meeting held in St. Paul's Church for the purpose of electing a vestry clerk, supporters of incumbent Roche cheered their favorite. Those who backed candidate Corder were parishioners in favor of instituting an open vestry. The latter group loudly booed and hissed the incumbent. Roche won the election.

828-03-26-02 Without consulting non-select parishioners, the Select Vestry had drawn up a list of candidates from which local Magistrates were to appoint two Overseers. Non-select parishjoners subsequently held a Petty Session in the vestry-room of St. Paul's Church, Mr. 
Dow presiding. After eight men had been chosen for recommendation, the meeting was disrupted by Magistrates Sir Richard Birnie and Thomas Halls. Refusing a suggested compromise, the Magistrates appointed two overseers from the Select Vestry list. The meeting closed with an angry exchange between Dow and Sir Richard.

828-04-08-01 Open Vesiry proponents had recently defeated a bill designed to impose the Select Vestry on their parish. A two-day Open Vestry was held in the aisle of St. Paul's Church for the purpose of electing parish officers. The Select Vestry candidate for Vestry Clerk, incumbent Roche, was defeated by Open Vestry candidate, Corder.

828-04-17-02 Gathering at the Piazza Coffee-House, parishioners resolved that their deposed Vestry Clerk be compelled to relinquish the parish books to his successor.

828-06-06-02 A meeting was convened in the vestry room of St. Paul's Church. Inhabitant householders determined to bring the former Vestry Clerk before the King's Bench for refusing to surrender parish records. Parishioners also decided to petition Parliament for repeal of certain acts affecting the local vestry, which they felt had caused turmoil in the parish.

828-09-26-01 A violent encounter between Irish and English porters took place in Covent Garden Market. Irish workers used spades, pickhandles, and rocks against their unarmed opponents. An unspecified number of injuries resulted, and twelve men were arrested.

St. Paul's, Covent Garden: Routine Assemblies

On 18 January an election was held for vestry clerk. The hustings were crowded with electors and spectators. There was much shouting and applauding of the candidates.

On 20 January a crowd gathered to hear a preacher speak on the street corner and blocked up an intersection, so numerous were they.

London (in General): Routine Assemblies

At Newgate Prison on 12 March "the concourse of people assembled on the occasion was greater than had been known for a considerable time." The occasion was the hanging of five young men for a robbery conviction.

The Guildhall played host to a Grand Morning Concert for the benefit of the Spanish and Italian refugees. This is one in a long history of such benefit concerts at the Guildhall over the 1828-34 period.

On 9 January the annual meeting of the Association for the Relief of the Poor of the City of London was held at the London Coffechouse, Ludgate-hill. This is one of the many hundreds of such meetings that happen every day in coffechouses and taverns throughout the London area.

\section{NOTES}

1. The National Endowment for the Humanities supports the research described in this paper. We are grateful to Raul Onoro, Keith Clarke, Amy Alpert, Mary Parks, Madeleine McCarney, and the rest of our research group for help in preparing the materials presented in this paper, and to Sheila Wilder and Debby Snovak for help in producing it. The paper is a condensed version of "The Changing Geography of Contention in London, 1755-1835: Sketch of a Research Plan," Working Paper 225, Center for Research on Social Organization, University of Michigan, January 1981. The 74-page working paper includes extensive bibliographies and illustrative materials we have omitted from this version.

2. Robert Southey, Colloguies on Society (London, 1894; first published in 1824), p. 108.

3. British Museum, Add. MSS 27,789, fo. 227.

4. D. A. Reeder, "A Theatre of Suburbs: Some Patterns of Development in West London, 1801-1911," in H. J. Dyos, ed., The Study of Urban History (London, 1968), p. 255.

5. George Rudé, Paris and London in the Eighteenth Century (New York, 1971), p. 10.

6. John Stevenson, Popular Disturbances in England, 1700-1900 (London, 1979), p. xxiii.

7. Robert Southey, "On the State of the Poor," in Essays, Moral and Political (London, 1832; first published in 1812), vol. I, p. 120.

8. Daniel Lysons, The Environs of London: Being an Historical Account of the Towns, Villoges, and Hamlets, within Twelve Miles of that Capital (London, 1811), pp. 294-337. 
The Center for Research on Social Organization is a facility of the Department of Sociology, University of Michigan. Its primary mission is to support the research of faculty and students in the department's Social Organization graduate program. CRSO Working papers report current research and reflection by affiliates of the Center; many of them are published later elsewhere after revision. Working Papers which are still in print are available from the Center for a fee of $\$ .50$ plus the number of pages in the paper ( $\$ .88$ for a 38-page paper, etc.). The Center will photocopy out-of-print Working Papers at cost (approximately $\$ .05$ per page). Recent Working papers include:

260 "The Implications of National Service for Corrections," by James B. Jacobs, April 1982,29 pages.

261 "Conflict and Change in France Since 1600, As Seen From a Very Small Place," by Charles Tilly, April 1982, 30 pages.

262 "Five French Regions, Four Contentious Centuries, Two Fundamental Processes, By Charles Tilly, April 1982, 26 pages.

263 "Flows of Capital and Forms of Industry in Europe, 1500-1900," by Charles Tilly, April 1982,36 pages.

264 "A Memoir," by Bruno Bettelheim, April 1982, 16 pages.

265 DRAFT "The Background and Present State of the Controversy on Social Control in Science," by Joseph Ben-David, April 1982, 25 pages.

266 "American Conservatism and Government Funding of the Social Sciences and the Arts", by Jerome L. Himmelstein and Mayer N. Zald, May 1982, 23 pages.

267 "A British View of American Stikes", by Roberto Franzosi and Charles Tilly, May 198223 pages.

268 "Changing Patterns in the Social Organization in the Coffee Export Sector in Sao Paulo, 1889-1930," by Mauricio A. Font, May 1982, 68 pages.

$269^{\circ}$ "The United Farm Workers Union: From Mobilization to Mechanization?" by Robert J. Thomas and William H. Friedland, June 1982, 84 pages.

Request copies of these papers, the complete list of Center Working Papers and further information about the Center activities from:

Center for Research on Social Organization

University of Michigan

330 Packard Street

Ann Arbor, Michigan 48109 